\title{
Unpacking the Nordic Gender Equality Paradox in ICT Research and Innovation
}

\author{
Hilde G. Corneliussen ${ }^{1 *}$
}

Published: September 1, 2021

\begin{abstract}
Most fields of technology-driven research and innovation are highly male-dominated across the Western world. However, in the Nordic countries, recognised as the most gender equal in the world, this gender segregation appears as a paradox. With Norway as an example, the present article explores the paradox that appears to be entangled with the yet unsolved question of why women are still a minority in information and communication technology (ICT) disciplines. The analysis draws examples from five studies of girls and women in contexts of ICT training, education, and work to analyse the fabric of the paradox through the 'free choice' argument, 'affluent nations' argument, and 'nation vs. individual women' argument. The analysis suggests that the paradox, by putting the nation's gender equality ideal against atomized individuals' choices, contributes to obscuring the situation regarding the underrepresentation of women in ICT.
\end{abstract}

Keywords: gender equality paradox, gender equality ideal, Nordic countries, ICT, horizontal gender segregation

\section{INTRODUCTION: THE NORDIC GENDER EQUALITY PARADOX}

Norway and its Nordic neighbours are recognised as the most egalitarian countries in the world according to international ratings (Teigen and Skjeie, 2017; World Economic Forum, 2020). There is, however, still notable gender segregation, identified as vertical segregation where few women are in top positions and horizontal segregation with gender division between occupations and disciplines, a pattern that appears to be in conflict with the perception of gender equality as a widespread and accepted value (Ellingsæter, 2014; Sund, 2015). Furthermore, the notion of paradox is often invoked in international comparisons where certain types of gender segregation seem to be more extreme in highly gender egalitarian and affluent countries (Chow and Charles, 2019; Stoet and Geary, 2018), often referred to as a Nordic gender equality or gender diversity paradox (Minelgaite et al., 2020).

In this article we will unpack the Nordic gender equality paradox in relation to the horizontal segregation recognised in fields of information and communication technology (ICT), where the paradox is entangled with the yet unsolved question of why women are still underrepresented in most ICT disciplines and jobs. Supported by research and theories from feminist technology studies and studies of gender segregation in working life, this study explores how the low proportion of women in ICT training, education, and employment translates into a paradox in affluent and gender-equal Nordic countries with Norway as an example. The rhetoric of the paradox is a strategic starting point for studying why the national gender equality regime fails to reach contexts of ICT, as it claims to identify important features explaining women's underrepresentation in ICT. International analyses of the paradox often involve three features. The first is an analytical framework in which a national gender equality regime is used as the horizon for explaining individual citizens' choices. The second is national affluence, used as a reference point for gender-stereotypical career choices. The third is an assumption that gender-equal countries promoting free choices put women's choices at the centre of the paradox, suggesting that the continuous gender imbalance in fields such as ICT mainly reflects women's preferences. Below we will explore the validity of these features as we revisit research on women's underrepresentation in ICT with a particular focus on women's entry points to ICT, in order to unpack how the paradox is shaped and reproduced across contexts of ICT.

The development of this study emerges from Nordwit, the Nordic Centre of Excellence on women in technology-driven careers, and the recognition of the challenge to recruit women to ICT careers (McKinney et al., 2008). This includes not only early-stage recruitment; recent research has shown that women often find alternative 
routes to developing their ICT competence and expertise (Hyrynsalmi and Hyrynsalmi, 2019; Lyon and Green, 2020), some at later stages in their career (Cajander et al., 2020; Corneliussen, 2020). This suggests that the contexts for raising girls' and women's engagement in ICT careers are many. ICT disciplines in social sciences and humanities often attract a higher proportion of women than ICT disciplines in faculties of science and technology (Corneliussen, 2011). Disciplines focusing on programming and more technical aspects of computing often have the lowest proportion of women (Samordna opptak, 2020). Research shows that the perceptions of programming are more affected by gender stereotypes than those of many other fields of ICT (Corneliussen, 2020). The studies revisited here involve various fields of ICT training and education that include either programming or ICT disciplines in science and technology faculties. The analysis draws examples from five studies of girls and women in contexts of ICT training, education, and work to analyse the fabric of the paradox through the 'free choice' argument, 'affluent nations' argument, and 'nation vs. individual women' argument. Revisiting these studies will help to identifying the validity of the rhetoric of the paradox when confronted by empirical examples.

\section{THE FABRIC OF THE NORDIC GENDER EQUALITY PARADOX}

The Nordic countries have a long tradition of working toward gender equality in politics, education, and working life. High governmental engagement has been instrumental in developing a 'women-friendly state' (Hernes, 1987) and family-friendly work-life policies that have secured high participation of women in paid work (Seierstad and Kirton, 2015; Statistics Norway, 2018). Norway, like the other Nordic countries, scores exceptionally high on rankings measuring various equality indicators (Teigen and Skjeie, 2017). The notion of a Nordic paradox is invoked because there is simultaneously a notable vertical and horizontal gender segregation in education and working life (Ellingsæter, 2014). Thus, the Nordic gender equality paradox appears as a contradiction between gender equality as a national ideal and the actual lack of gender diversity in working life- a gap between theory and practice (Minelgaite et al., 2020).

The Nordic aspect of the paradox comes into view in international rankings of countries' level of gender equality and in comparison with less gender-equal countries. The Global Gender Gap Report 2020 (GGGR), published by the World Economic Forum, ranks countries according to indicators for economic participation, educational attainment, health, and political participation. The GGGR ranks Iceland, Norway, Sweden, and Finland as the 'most gender-equal countries in the world' (World Economic Forum, 2020, p. 25). Although there are differences between the Nordic countries, wherein Norway is regularly placed in the middle, the Nordic countries' gender equality model clearly stands out as exceptional compared with other European Union countries (Teigen and Skjeie, 2017). Simultaneously, these four 'most gender-equal countries' are surpassed by, for instance, Bulgaria at $49^{\text {th }}$ place on the GGGR in terms of the proportion of female professors (European Commission, 2019) and the proportion of women in the ICT sector (Simonsen and Corneliussen, 2020). The paradox is shaped by a failed expectation of gender equality in one field leading to gender equality in other fields (Ellingsæter, 2014, p. 101).

The Nordic gender equality paradox has been discussed in relation to vertical (Minelgaite et al., 2020; Teigen, 2014) and horizontal gender segregation (Charles and Bradley, 2006; Charles and Thébaud, 2018; Chow and Charles, 2019) as well as with regard to societal issues (Wemrell et al., 2019). Researchers have pointed out that vertical and horizontal gender segregation have different origins and explanations (Reisel, 2014; Sund, 2015). Suggesting that women lack abilities to take on top positions, for instance, is not acceptable within a discourse of gender equality (Charles and Grusky, 2005; Ellingsæter, 2014). Thus, the gender equality ideology has challenged vertical gender segregation and resulted in measures to increase gender diversity in top positions in Nordic countries (Minelgaite et al., 2020). Horizontal gender segregation, in contrast, is more often described in terms reflecting a gender essentialist notion of men and women as suitable for different, supposedly complementary, tasks and occupations. Horizontal segregation thus appears to reflect men's and women's career preferences (Ellingsæter, 2014). According to Charles and Bradley (2009), horizontal segregation is 'less politically and socially contested than are many types of vertical inequality' (p. 930). Ellingsæter (2014) suggests that horizontal gender segregation mainly reproduces gender inequality in Norwegian working life, which is legitimised through gender essentialist ideas. The horizontal gender segregation in fields of ICT and how this can be understood through explanations to the paradox are the focus of the analysis below.

Three features appear to be of importance for the notion of the Nordic gender equality paradox in relation to horizontal segregation. First, international comparisons invoking the notion of the paradox typically rely on an explanation based on the nation vs. the individual (Minelgaite et al., 2020). Researchers have, for instance, studied the gender gap in fields of ICT for decades, and among the most critical challenges recognised today are gender stereotypes associating ICT with men rather than with women (Corneliussen and Seddighi, 2020; Master et al., 2016; Sagebiel, 2016). This makes computing appear as a masculine arena and demotivates girls to engage (Blum et al., 2007; Corneliussen, 2020; European Institute for Gender Equality, 2018). Although these and other explanations from social science and psychology are recognised in international comparisons, such factors often 
remain in the periphery of the paradox, suggesting a pattern wherein the goal of a 'gender equal' nation is not fulfilled by its atomised individuals. Stoet and Geary (2018) illustrate this in their analysis of girls' performance in STEM (science, technology, engineering, and mathematics) across 67 countries participating in the PISA 2015 (OECD, 2017) assessment of student achievement:

One of the main findings of this study is that, paradoxically, countries with lower levels of gender equality had relatively more women among STEM graduates than did more gender-equal countries. This is a paradox, because gender-equal countries are those that give girls and women more educational and empowerment opportunities and that generally promote girls' and women's engagement in STEM fields (Stoet and Geary, 2018, p. 590).

Combining the analytical levels of the nation, on one hand, and individuals, on the other, points at a gap between a societal level of gender equality value and an individual level of attitudes and behaviours that contributes to the paradox (Minelgaite et al., 2020). Furthermore, because the national level of gender equality is already 'confirmed' in ratings such as the GGGR, it remains to find the explanation elsewhere, such as in individual women's preferences and choices.

The second feature of the paradox is associated with national affluence. Nordic countries scoring high on gender equality measures are also typically affluent welfare states. Affluence thus appears to be one of the differentiating factors between countries that are divided by the gender equality paradox, again illustrated by Stoet and Geary (2018, p. 590):

In our explanation of this paradox, we focused on decisions that individual students may make and decisions and attitudes that are likely influenced by broader socioeconomic considerations.

The link between national affluence and women's underrepresentation in fields such as ICT is interpreted as a reflection of the national economic situation, suggesting that 'life-quality pressures in less gender-equal countries promote girls' and women's engagement with STEM subjects' (Stoet and Geary, 2018, p. 581), whereas women in more affluent countries do not experience a similar pressure in their study choices. This interpretation suggests that national affluence is considered instrumental in reproducing women's underrepresentation in fields such as ICT. However, this interpretation also includes an image of men as rational actors that avoid low-paid 'women's jobs', whereas women appear less ambitious and as the ones who choose work in accordance with gender identity (Ellingsæter, 2014). The image of national gender equality combined with a welfare state and affluence produces an image of the national egalitarian values endorsing women's 'right to choose poorly paid female-labeled career paths' (Charles and Bradley, 2006, p. 195). This points to the third argument feeding the notion of a paradox: the 'free choice' argument.

Women's career choice is the main target even for this argument, not so much in terms of ambition but rather with reference to women's preferences.

Sex segregation by field of study is widely understood to represent the outcome of free choices by autonomous, but fundamentally gendered, individuals (Charles and Bradley, 2009, p. 961).

The perception of a free atomised individual making choices in a context of a democratic, free, and gender-equal nation makes choices appear to reflect individuals' preferences (Ellingsæter, 2014).

The magazine The Atlantic's coverage of Stoet and Geary's (2018) study suggests that this type of gender essentialist explanations to horizontal segregation resonates with a popular discourse:

The upshot of this research is neither especially feminist nor especially sad: It's not that gender equality discourages girls from pursuing science. It's that it allows them not to if they're not interested (Khazan, 2018, February 18).

Gender equality is this way translated into a freedom that produces and endorses gender difference and the paradox rhetoric contributes to a narrative in which women's choice is a key to gender divides in the labour market. Simultaneously, this exempts other actors' and institutions' relevance when aiming to understand patterns of horizontal gender segregation. This will be further explored below through empirical studies of girls and women in contexts of ICT training, education, and work and by confronting the central findings from these studies with the three features that make up the fabric of the Nordic gender equality paradox: the 'nation vs. atomised individuals' argument, 'affluent nation' argument, and 'free choice' argument. 


\section{METHODOLOGICAL FRAMEWORK}

The analysis below is based on studies of girls' and women's participation in ICT training and education in Norway between 2000 and 2020. Two studies focus on women's study choice when entering ICT disciplines. The first includes 3 months of observation in programming classes and in-depth interviews with 21 women and 7 men taking a university course in programming (Corneliussen, 2003). A discourse theoretical framework (Laclau and Mouffe, 1985) contributed to the analysis of how men and women position themselves in relation to a gendered discourse about computing. Twenty years divide the first and the second study, which includes in-depth interviews with 24 female students and women in academic recruitment positions in ICT disciplines within science and technology faculties. This study explores how and when women's decisions to enter ICT disciplines are shaped (Corneliussen, 2020, 2021).

Two studies focus on how girls are included in arenas for coding and programming; the first is a study wherein Lin Prøitz and myself visited a code club and interviewed children, parents, instructors, and teachers from the local school (Corneliussen and Prøitz, 2016). The second study explores the recruitment of girls to a pilot elective in programming for schoolchildren in Grade 8, 9, and 10. This study includes a survey among schools analysing the gender distribution as well as interviews with girls and school representatives conducted by Fay Tveranger (Corneliussen and Tveranger, 2018).

The final study focuses on how ICT organisations and employers perceive and deal with women's underrepresentation. This study builds on individual dialogue meetings for discussing this topic with 12 organisations and a total of 13 women and 10 men, where Gilda Seddighi also participated (Corneliussen and Seddighi, 2019; Corneliussen and Seddighi, 2020). The study aimed to understand how the organisations' representatives engage with a national gender equality ideal and how they respond to a call for gender equality action to increase diversity in ICT disciplines.

All the above-mentioned studies were designed within the framework of feminist technology studies (FTS), emphasising technology as socially produced and shaped by culture and society. An important insight from FTS is the emphasis on the mutual relationship between, and the co-construction of, gender and technology (Cockburn, 1992). Gender, in this perspective, is not predefined or fixed but is a fluid and flexible identity (Braidotti, 2002) that is culturally enacted and performed (Butler, 1993; West and Zimmerman, 1987). This perspective is also a foundation for the analysis below. The analysis involves a feminist discursive approach encouraging 'a critical stance towards taken-for-granted knowledge' (Livholts and Tamboukou, 2015). Discourse in this context refers to a widespread attitude in a certain field, and the analysis aims to explore how meaning is constantly negotiated and re-constructed (Laclau and Mouffe, 1985).

The analysis below aims to further entangle the main features of the notion of a Nordic gender equality paradox and to explore the validity of the paradox when confronted with empirical examples of girls' and women's participation in ICT training, education, and work. Explanations to the paradox reviewed above are built on a national image of gender equality that apparently is interrupted by women's individual choices, which makes sense within a neoliberal framework that favours governance techniques that make citizens become 'responsible citizensubjects' (Ferguson, 2009, quoted in Budgeon, 2015, p. 304) 'who willingly respond to incentives' in ways that make state intervention less important (Budgeon, 2015, p. 304). This implies an image of the state facilitating for individuals to make the 'right' choices. The question of women's choice has followed feminist debates for several decades (Banet-Weiser et al., 2020), and Gill (2007) discusses this in terms of a 'postfeminist sensibility'. 'Postfeminism' is not a branch of feminism but rather refers to a type of reaction or a discourse assuming that structural issues that previously created gender differences have been removed and that any remaining gender inequality 'can be accounted for by choices knowingly made by individuals' (Budgeon, 2015, p. 304). Responsibility for gender segregation is consequently moved from structures defining the nation to the individuals. This contributes to a perception of gender-typical career choices as a legitimate result of free choices and therefore as something that needs to be supported (Ellingsæter, 2014, p. 87).

The analysis below will engage with the ideas reflected by these concepts and show how neoliberal ideas of the state facilitating for autonomous individuals and the 'postfeminist sensibility' assuming that women's choices are a reflection of what they want contribute important insights to the co-construction of gender and technology in the rhetoric of a gender equality paradox.

\section{SEEING WOMEN'S PARTICIPATION IN ICT THROUGH THE FABRIC OF THE PARADOX}

The fabric of the paradox has been identified as an entanglement including a nation vs. individual level of analysis, seeing women's choices as a reflection of national affluence, and treating the gender imbalance in male- 
dominated fields, such as ICT, as a result of women's free choices. In the analysis below, we will explore these three arguments more in depth in relation to girls and women in ICT training, education, and work in Norway. We will start with the 'free choice' argument considered in light of women's study choices. Next, we will explore the validity of the 'affluence nation' argument analysed in light of code clubs and programming in schools. Finally, we will explore the 'nation vs. individual women' argument in light of employers' attitudes toward gender segregation in ICT jobs and the ICT sector.

\section{The 'free choice' argument's validity for women's decisions to study ICT}

The argument of 'women's choice' as a crucial feature of the Nordic gender equality paradox rests on the notion of the autonomous individual choosing according to preferences (Charles and Bradley, 2006) and achievements (Stoet and Geary, 2018). In a study of men and women in a university ICT program, a clear difference was observed in how the men and women described their feeling of belonging in the programming class. Whereas some men suggested there was a special male relationship with computers that made it easier for them to learn programming, several women described the programming class as an 'unexpected' venture into 'a masculine, forbidden world' (Corneliussen, 2003). Two feelings stood out in the women's narratives: pleasure about having the opportunity to learn programming and surprise that they were able to do it. One of the women who was struggling with the programming structures, however, claimed the struggle was 'because I am a woman' (Corneliussen, 2003). The women's narratives illustrate how their experiences are enclosed by a discourse defining ICT as a masculine field. The surprise and pleasure they expressed over learning to program suggest that the decision they had made was not only about interest in ICT but also about entering a masculine field that did not appear inviting for women.

The next example fast-forwards 20 years, to a study of what made female students and women in early research positions choose ICT disciplines in science and technology departments and universities. One of the most important periods for recruiting girls to ICT careers is the transition from high school to higher education, but most of the women in the study had not thought about ICT as a potential career choice at that time. Their narratives suggest that this viewpoint was a result of little concrete knowledge about ICT disciplines and even less about ICT work combined with an expectation that ICT studies at universities are filled with 'hooded gamers': young men whom they imagined had been gaming and programming since their early teens. Most of the women told stories about choosing ICT despite these barriers, in particular, stereotypical notions of ICT as a masculine field in which they did not see themselves fit in. Only five women identified as interested in ICT already during secondary or high school; however, knowing little about relevant ICT programs, they found it difficult to know which subject to choose. Ten of the women had first signed up for another study program, but after gaining more insights regarding ICT and, in particular, regarding programming, they came to see ICT as a relevant choice for themselves and subsequently decided to change to study a program in ICT, which for some meant starting on a second bachelor's degree. Most of the women, however, told a story of not being interested in ICT; thus, they described the decision to study ICT by referring to interest and professional strength in a different field in science, social science, or humanities that offered them a 'safe and well known' platform within ICT:

Math was probably my strongest subject ever since I was young. So, then I thought I had something I could feel confident about while learning something new (Corneliussen, 2021).

Nearly half of the women identified their strength in mathematics, whereas other fields of science and social sciences also took the role as a safe platform in the women's narratives. The platform allowed them to define their belonging in ICT in ways that did not compete with the image they had of the male ICT students (Corneliussen, 2021). Similar to the women interviewed 20 years ago, these women also struggled with a masculine discourse of ICT that appeared as an obstacle for them to express their interest in ICT. The detour via other fields before 'discovering' ICT works as a 'penalty round' for women, as they have to spend extra time after high school to gain insights regarding ICT as an academic field. For some, this also included building courage to enter a field where they assumed they would never really be able to compete with men based on their image of men's experience, like one of the women illustrates: 'they are so skilled that it feels completely unattainable to be as good as them' (Corneliussen, 2021). Once the women had actually started at their chosen ICT program, they found many reasons for developing both interest and a feeling of belonging in ICT. Contrary to the stereotypical notion of programming as more attractive for men than for women, programming was one of the topics that made the women 'fall in love' with ICT, with one saying, 'I can't explain the joy I got from my first programming class', and another suggesting, 'If I had known about the possibilities before, I would have sat down and started programming right away'.

Although these examples should not be read as a general description valid for all women, neither should they be considered unique, as similar findings are reported across research projects (Frieze and Quesenberry, 2019; Master and Meltzoff, 2020; Vainionpää et al., 2019). What they do illustrate is that the paradox rhetoric emphasising 
individual women's choices obscures a situation where the young women experienced a culture defining ICT as a masculine field and with little welcome for women.

\section{The 'affluent nation' argument in light of recruitment arenas for children}

International studies have suggested that because ICT is culturally associated with boys and men, girls need to be recruited early, typically during their teens, before gender stereotypes about ICT start dominating their ideas (Cheryan et al., 2013; Microsoft Corporation, 2017). Whereas primary schools in Norway did not offer ICT as a specialist field (e.g., computer science), afterschool 'code clubs' inviting children to learn to program started spreading in the 2010s (Corneliussen and Prøitz, 2016). Descriptions of code clubs as an arena that also included girls raised our curiosity and resulted in a research project where we observed and interviewed a wide selection of participants associated with a code club: children, parents, instructors, and a local school's head teacher and teachers (Corneliussen and Prøitz, 2015, 2016).

The instructors, parents, and teachers involved in the code club compared learning about programming with learning about society and described it as a 'necessity for becoming a good/efficient/empowered citizen in our digital society' (Corneliussen and Prøitz, 2016, p. 106). The code club was open for all children aged 11 to 12 years; however, very few girls participated. The interviews suggested that these young boys and girls had not yet internalised (Berger and Luckmann, (1966) 1991) ICT as a field only for boys and they questioned the absence of girls. The involved parents, instructors, and teachers also recognised the gender imbalance at the club. However, they did not question this and rather admitted that they had not given it much thought because low participation by girls was what they expected to see; it was what 'we have been used to' (Corneliussen and Prøitz, 2016, p. 104). Recognising the low number of girls while not pursuing any strategy to recruit girls indicates that the gender imbalance in the club was accepted as a documentation of boys and girls as different (Corneliussen and Prøitz, 2016), in line with a gender essentialist attitude welcoming gender difference.

The trend of teaching children coding also reached the schools in Norway in 2016 through a pilot for programming as an elective in secondary schools. Studying the pilot, we found that the schools placed very little focus on recruiting girls and only $16 \%$ of the pupils in the programming classes were girls. Several schools and more than a hundred programming classes did not engage even a single girl (Corneliussen and Tveranger, 2018). Our question about whether it would be possible to recruit more girls was often met with doubt or was even rejected by parents and school representatives with the explanation that girls are not interested in ICT. Thus, here we found a circular pattern wherein a low proportion of girls justifies a lack of initiatives to engage girls.

Returning to the paradox and the affluence argument, it is difficult to identify a link between national affluence and girls' choices in these examples. What we can identify is rather a pattern of adults who should have been the young girls' supporters and door openers to the code clubs and programming classes that have given up on recruiting girls because they think girls are not interested and that it is not within their power to change the situation. This pattern also highlights how girls' choices cannot be seen as isolated events produced by girls alone but are rather entangled in a web of gendered discourses of ICT that permeate contexts and actors that go far beyond girls' control.

Initiatives to recruit girls to STEM fields have promoted the idea of producing a 'girl-centric ecosystem' based on a conviction that collaboration between a diverse set of actors is necessary for creating inclusive learning environments (Traphagen and Traill, 2014).

STEM workforce issues will only be solved by diverse partners collaborating to create disruptive solutions that promote equity for all girls and underrepresented racial minorities. (...) We need organizations to work on different parts of a girl-centric STEM ecosystem (Sammet and Kekelis, 2016, p. 5).

The 'ecosystem' is a suitable image of the environment, for instance, around a code club, with an assemblage of actors, institutions, attitudes, opportunities, physical meetings, hands-on practice with programming, and moreonly that the code club ecosystem is not 'girl-centric'.

\section{The 'nation vs. individual women' argument and employers' attitudes toward gender equality work}

The last example is from a study of how employers and organisations in fields of ICT research and innovation perceive and deal with the low proportion of women in ICT jobs (Corneliussen and Seddighi, 2019; Corneliussen and Seddighi, 2020). Twelve employers and organisations with a total of 13 women and 10 men in the field of ICT research and innovation participated in 2018 and 2019 in dialogue meetings to discuss the underrepresentation of women in ICT work. All the organisations' representatives agreed to gender equality as a goal in society, demonstrating Brown's description of gender equality as something we 'cannot not want' (2000, p. 238). When the representatives were asked to reflect on how they dealt with this issue in their own organisation, they revealed a series of alternative approaches and reasons for not making gender equality a goal in ICT. For some, it was the 
presence of women in other positions that obscured the goal of recruiting women to ICT positions: they did not feel that they needed to recruit more women. Other companies with fewer female employees that also struggled to recruit women to ICT positions, found a solution by recruiting women to, for instance, HR positions instead. One ICT company without any women in ICT positions considered gender equality as already achieved because 'everybody is treated the same' (Corneliussen and Seddighi, 2020, p. 44). Another suggested that targeting women when recruiting could have 'the opposite effect' (Corneliussen and Seddighi, 2020, p. 45) and therefore continued to rely on what they considered 'gender-neutral' strategies. One ICT company suggested that because boys develop their interest in ICT early, they have an advantage in building their knowledge in ways with which women cannot compete. Consequently, this line of argumentation raised doubts about women's competence in ICT.

This study illustrates two elements that can help to identify how the gender equality paradox is shaped. First, it shows the wide acceptance of the national gender equality regime, which is not questioned but rather accepted by the organisations' representatives, also when renegotiating what gender equality means in the context of their own organisation. Second, the study shows that the idea of a national gender equality regime coexists with discourses of ICT as a male-dominated field including gender stereotypes that leave little space for establishing gender equality as a goal for ICT positions. Because making changes (e.g., those affecting women's preferences) appears out of reach for the organisations, they do not consider themselves as being in breach with the general ideas of gender equality.

\section{DISCUSSION}

The aim of this study was to explore how the low proportion of women in academic fields of ICT and ICT work translates into a paradox in the affluent and highly gender egalitarian Nordic countries with Norway as an example. The paradox refers to the mismatch between a perception of a national gender equality regime and a lack of realising gender equality goals in certain fields: a failed expectation of gender equality in one field leading to gender equality in other fields (Chow and Charles, 2019; Ellingsæter, 2014; Minelgaite et al., 2020; Stoet and Geary, 2018). The Nordic gender equality paradox typically appears in international comparisons, showing this pattern to be more extreme in gender egalitarian, democratic, and affluent Nordic countries (Minelgaite et al., 2020). The analysis above focused on the horizontal gender segregation in Norway in fields of ICT. The aim of revisiting research on girls' and women's participation in ICT training, education, and work was to unpack how the paradox manifests itself in contexts of ICT. The analysis focused on three features that contribute to making women's underrepresentation in fields such as ICT appear as a paradox: the 'free choice' argument, 'affluence nation' argument, and 'nation vs. individual women' argument.

The 'free choice' argument assumes that gender barriers have been removed in the gender egalitarian Nordic countries and therefore women's choices must reflect their preferences (Stoet and Geary, 2018). The analysis showed examples from 20 years apart of how young women perceive ICT as a masculine field and how images of male ICT experts, like the 'hooded gamer' who has programmed since he was young, appear as obstacles for women to even express their interest in ICT. Thus, whereas the paradox infers that a positive preference, such as interest, is a main driving force for choosing to study ICT, the women's narratives illustrate a struggle with a discourse challenging women's image of themselves as (future) ICT experts. Thus, the women's stories do not support the 'free choice' argument but rather point to how a combination of a masculine discourse of ICT and lack of knowledge about it makes ICT an invisible career choice for women.

The next example illustrates how this is further complicated when the low proportion of women in ICT works as a circular motivation for the lack of engagement in recruiting girls to ICT. The 'affluent nation' argument suggests that women in wealthy countries do not feel the same urgency to choose high-paid jobs as women in poor countries (Stoet and Geary, 2018) and they appear to be less ambitious than men in their own country (Ellingsæter, 2014). This argument is generally not supported by the fact that women make up $60 \%$ of the applicants to higher education and are a majority in high-status fields such as medicine and law in Norway (Samordna opptak, 2020). The examples of the code club and programming in school served to illustrate how a masculine discourse of ICT made parents, instructors, and teachers less motivated to target girls with invitations to coding or programming. Even when ICT is recognised as vital for becoming a 'successful citizen', girls are often left out of arenas for ICT training in ways that remain 'invisible' and that are perceived as a natural reflection of gender differences rather than, for instance, concerns being raised about how to increase diversity in the field or how to build, if not a 'girlcentric', at least a 'gender inclusive' ecosystem. Thus, women are not alone in making choices that reproduce gender imbalance in ICT, which also indicates that the concurrence of national affluence and women's choices does not mean that one explains the other.

Exploring the third feature of the paradox, the 'nation vs. individual women' argument, further emphasises that women's actions alone cannot explain the entire paradox by highlighting ICT employers' and organisations' responses to the lack of diversity in this sector. The empirical examples show how these groups agreed with a 
general gender equality ideal and simultaneously expressed doubts about the possibility as well as necessity of recruiting women to ICT positions. A masculine discourse of ICT raises doubts about women's engagement, resulting in organisations' weak motivation to work for gender diversity in ICT jobs. The examples illustrate a widely accepted national gender equality regime existing in parallel with attitudes and practices that make fields of ICT appear less welcoming to girls and women but that take place in such a subtle way that it appears as if the gender equality ideal itself is not questioned. The analysis illustrates the need to study the context of girls' and women's choices as they take place within contexts wherein girls and women are not the only contributing actors.

Thus, as illustrated above, treating the underrepresentation of women in ICT as part of a gender equality paradox is problematic for several reasons. First, the rhetoric of the paradox seems to rest on a neoliberal idea of the state facilitating for individuals to make the 'right' choices (Ferguson, 2009) combined with a postfeminist 'sensibility' that considers gender equality as already achieved and therefore considers the remaining inequalities as a result of women's choices reflecting what they want (Banet-Weiser et al., 2020, p. 5). This paves the way for gender essentialist ideas to figure as explanations and further makes it appear as a good strategy to defend women's rights to choose according to their preferences (Ellingsæter, 2014). Whereas free choices are certainly a democratic good, this paradoxical thinking contributes to a perception of the paradox as a result of unchangeable gender differences and takes the focus away from structures and practices that continue to produce inequality, also independent of women's own choices. The examples put forward illustrate how the rhetoric of the paradox frees relevant actors from their contribution and responsibility in developing inclusive cultures in ICT training, education, and work.

Thus, whereas the gender equality ideology is recognised as delegitimising vertical segregation (Charles and Grusky, 2005; Ellingsæter, 2014; Reisel, 2014), the analysis above suggests that the national gender ideal combined with a postfeminist sensibility has the effect of legitimising the horizontal segregation. The employers, parents, teachers, and others we have interviewed do not feel they are in breach with the gender equality ideal; they are simply adjusting according to their context and their expectations of girls' and women's interest in ICT. The result is the renegotiation of gender equality as less relevant in ICT that is discursively happening from inside the national gender equality regime. This leaves the national ideal intact while explaining the lack of gender equality in line with gender essentialist ideas and women's choices reflecting a postfeminist assumption of gender barriers already being removed. In this way, the national gender equality regime is distorted into authorising the lack of gender equality actions in the context of ICT (Corneliussen and Seddighi, 2019; Corneliussen and Seddighi, 2020) and the gender imbalance in ICT thus remains a challenge produced by women.

\section{CONCLUSION}

The aim of this study was to unpack the Nordic gender equality paradox in relation to women's underrepresentation in ICT, by exploring the validity of the paradox when confronted with empirical examples of girls' and women's participation in ICT training, education, and work. We have seen how the fabric of the paradox — the 'nation vs. individual women' argument, 'affluent nation' argument, and 'free choice' argumentworks to promote some types of explanations, while simultaneously making other mechanisms producing gender imbalance in ICT invisible. The paradox simplifies the situation by emphasising the nation on one hand and individual women on the other. Using this nation vs. atomised individuals argument as the foundation for analysis risks making causal connections between elements that do indeed coexist but may not explain each other. Women in Norway and the Nordic countries are, for instance, free from many barriers and limitations found in less gender egalitarian, less democratic, and less affluent countries (Barbieri et al., 2020; World Economic Forum, 2020). Contrary to the idea of free choices and preferences driving study choice, the empirical research revisited suggests that there is still a series of barriers to ICT affecting girls more than boys. Furthermore, it suggests that girls and women are not the only ones making choices that result in a continuous gender inequality in ICT, indicating that a more finely tuned analysis is needed to account for the paradox.

Sund (2015) suggests that 'gender equality in Norway is perhaps more of an illusion than reality' as long as it is 'a commonly held value, but this is not reflected in the actual gender diversity situation' (p. 180). Here, we have seen examples of how the notion of a Nordic paradox simultaneously assumes that gender equality is already achieved on a national level while notable gender segregation exists in education and working life. The analysis suggests that as long as the horizontal gender segregation is defined as a consequence of women's choices, other actors' (lack of) contributions are ignored, thus practices reproducing women's underrepresentation in ICT can continue in perfect harmony with the national gender equality regime. This situation appears as a paradox because the starting point - the nation - is the already acclaimed winner of gender equality, leaving women at fault. The examples above show that a change of perspective is needed to encourage efforts not only to remove barriers for women's engagement in contexts of ICT but also to build ecosystems of more active initiatives targeting, inviting, and encouraging girls and women to enter fields of ICT. 


\section{ACKNOWLEDGEMENTS}

I want to thank my colleagues who have participated in some of the projects discussed above. I also want to thank all the participants who have contributed with their experiences in our research projects. This article was developed as part of Nordwit, funded by Nordforsk (www.nordwit.com).

\section{REFERENCES}

Banet-Weiser, S., Gill, R. and Rottenberg, C. (2020). Postfeminism, Popular Feminism and Neoliberal Feminism? Sarah Banet-Weiser, Rosalind Gill and Catherine Rottenberg in Conversation. Feminist Theory, 21(1), 3-24. https://doi.org/10.1177/1464700119842555

Barbieri, D., Caisl, J., Karu, M., Lanfredi, G., Mollard, B., Peciukonis, V., . . . Salanauskaite, L. (2020). Gender Equality Index 2020 - Digitalisation and the future of work. Luxembourg: EIGE (European Institute for Gender Equality).

Berger, P. and Luckmann, T. ((1966) 1991). The Social Construction of Reality. A treatise in the sociology of knowledge. UK: Penguin Books.

Blum, L., Frieze, C., Hazzan, O. and Dias, M. B. (2007). A Cultural Perspective on Gender Diversity in Computing, in C. J. Burger, E. G. Creamer and P. S. Meszaros (eds), Reconfiguring the Firewsall. Recruiting women to information technology across cultures and continents (pp. 109-133). Wellesley, MA: A K Peters, LTD.

Braidotti, R. (2002). Metamorphoses: Towards a materialist theory of becoming. Cambridge: Polity Press.

Brown, W. (2000). Suffering Rights as Paradoxes. Constellations, 7, 208-229. https://doi.org/10.1111/14678675.00183

Budgeon, S. (2015). Individualized Femininity and Feminist Politics of Choice. European Journal of Women's Studies, 22(3), 303-318. https:// doi.org/10.1177/1350506815576602

Butler, J. (1993). Bodies That Matter. On the discursive limits of "sex". New York: Routledge.

Cajander, Å., Corneliussen, H. G., Myreteg, G. and Dyb, K. (2020). What Brings Women into eHealth? Women's Career Trajectories in Digital Transformations in Healthcare, in M. Macedo (ed), Proceedings of the International Conference e-Health 2020 (pp. 71-77). IADIS: IADIS Press.

Charles, M. and Bradley, K. (2006). A Matter of Degrees: Female Underrepresentation in Computer Science Programs Cross-Nationally, in J. M. Cohoon and W. Aspray (eds), Women and Information Technology. Research on underrepresentation (pp. 183-203). Cambridge, Massachusetts, and London, England: MIT Press. https://doi.org/10.7551/mitpress/9780262033459.003.0006

Charles, M. and Bradley, K. (2009). Indulging Our Gendered Selves? Sex Segregation by Field of Study in 44 Countries. American Journal of Sociology, 114(4), 924-976. https:// doi.org/10.1086/595942

Charles, M. and Grusky, D. B. (2005). Occupational Ghettos: The worldwide segregation of women and men (Vol. 200). Stanford: Stanford University Press.

Charles, M. and Thébaud, S. (2018). Gender and STEM: Understanding segregation in science, technology, engineering and mathematics (special issue of Social Sciences). Basel, Switzerland: MDPI.

Cheryan, S., Plaut, V. C., Handron, C. and Hudson, L. (2013). The Stereotypical Computer Scientist: Gendered Media Representations as a Barrier to Inclusion for Women. Sex Roles, 69(1-2), 58-71. https://doi.org/10.1007/s11199-013-0296-x

Chow, T. and Charles, M. (2019). An Inegalitarian Paradox: On the Uneven Gendering of Computing Work around the World, in C. Frieze and J. L. Quesenberry (eds), Cracking the Digital Ceiling: Women in computing around the world (pp. 25-45). Cambridge: Cambridge University Press. https:// doi.org/10.1017/9781108609081.002

Cockburn, C. (1992). The Circuit of Technology: Gender, Identity and Power, in R. Silverstone and E. Hirsch (eds), Consuming Technologies: Media and information in domestic spaces (pp. 32-47). London: Routledge. https://doi.org/10.4324/9780203401491_chapter_2

Corneliussen, H. (2003). Diskursens makt - individets fribet: Kjonnede posisjoner i diskursen om data (The power of discourse the freedom of individuals: Gendered positions in the discourse of computing). Dr. art. Thesis, Dep. of Humanistic Informatics, University of Bergen.

Corneliussen, H. G. (2011). Gender-Technology Relations: Exploring stability and change. Basingstoke: Palgrave Macmillan.

Corneliussen, H. G. (2020). 'Dette har jeg aldri gjort for, så dette er jeg sikkert skikkelig flink på’-Rapport om kvinner i IKT og IKT-sikkerbet. Sogndal: VF-rapport 8/2020.

Corneliussen, H. G. (2021). Women Empowering Themselves to Fit into ICT, in E. Lechman (ed), Technology and Women's Empowerment (pp. 46-62). London: Routledge. https:/ doi.org/10.4324/9781003045946-3

Corneliussen, H. G. and Prøitz, L. (2015). Hvordan moter skolen okt frivillig engasjement for å lare barn koding? - erfaringer med koding for barn $i$ og utenfor skolen. Vestlandsforsking-rapport nr. 6/2015. 
Corneliussen, H. G. and Prøitz, L. (2016). Kids Code in a Rural Village in Norway: Could Code Clubs be a New Arena for Increasing Girls' Digital Interest and Competence? Information, Communication \& Society (Special Issue: Understanding Global Digital Cultures), 19(1), 95-110. https://doi.org/10.1080/1369118X.2015.1093529

Corneliussen, H. G. and Seddighi, G. (2019). 'Må vi egentlig ha flere kvinner i IKT?' Diskursive forhandlinger om likestilling i IKT-arbeid. Tidsskrift for kjonnsforskning, 43(4), 273-287. https://doi.org/10.18261/issn.1891-17812019-04-03

Corneliussen, H. G. and Seddighi, G. (2020). Employers' Mixed Signals to Women in IT: Uncovering How Gender Equality Ideals are Challenged by Organizational Context, in P. Kommers and G. C. Peng (eds), Proceedings for the International Conference ICT, Society, and Human Beings 2020 (pp. 41-48). IADIS: IADIS Press.

Corneliussen, H. G. and Tveranger, F. (2018). Programming in Secondary Schools in Norway - A Wasted Opportunity for Inclusion. Proceedings of Gender\&IT'18, Heilbronn, Germany, May 2018 (Gender\&IT'18) (pp. 172182). New York, NY, USA: ACM. https://doi.org/10.1145/3196839.3196867

Ellingsæter, A. L. (2014). Kjønnsessensialisme - segregeringens evighetsmaskin?, in L. Reisel and M. Teigen (eds), Kjonnsdeling og etniske skiller på arbeidsmarkedet (pp. 86-106). Oslo: Gyldendal Akademisk.

European Commission. (2019). She Figures 2018. Brussels: European Union.

European Institute for Gender Equality. (2018). Women and Men in ICT: A chance for better work-life balance - Research note. Luxembourg: EIGE: European Institute for Gender Equality, Publications Office of the European Union.

Ferguson, J. (2009). The Uses of Neoliberalism. Antipode, 41(1), 166-184. https://doi.org/10.1111/j.14678330.2009.00721.x

Frieze, C. and Quesenberry, J. L. (2019). Cracking the Digital Ceiling: Women in computing around the world. Cambridge: Cambridge University Press. https://doi.org/10.1017/9781108609081

Hernes, H. M. (1987). Welfare State and Woman Power. Essays in state feminism. Oslo: Norwegian University Press.

Hyrynsalmi, S. and Hyrynsalmi, S. (2019). What Motivates Adult Age Women to Make a Career Change to the Software Industry? Paper presented at the 2019 IEEE International Conference on Engineering, Technology and Innovation (ICE/ITMC). https://doi.org/10.1109/ICE.2019.8792630

Khazan, O. (2018, February 18). The More Gender Equality, the Fewer Women in STEM. The Atlantic. Available at: https://www.theatlantic.com/science/archive/2018/02/the-more-gender-equality-the-fewer-women-instem/553592/. (Accessed 21 April 2021).

Laclau, E. and Mouffe, C. (1985). Hegemony and Socialist Strategy. Towards a radical democratic politics. London: Verso.

Livholts, M. and Tamboukou, M. (2015). Discourse and Narrative Methods. Los Angeles: SAGE.

Lyon, L. A. and Green, E. (2020). Women in Coding Boot Camps: An Alternative Pathway to Computing Jobs. Computer Science Education, 30(1), 102-123. https:// doi.org/10.1080/08993408.2019.1682379

Master, A. and Meltzoff, A. N. (2020). Cultural Stereotypes and Sense of Belonging Contribute to Gender Gaps in STEM. International Journal of Gender, Science and Technology, 12(1), 152-198.

Master, A., Cheryan, S. and Meltzoff, A. N. (2016). Computing Whether She Belongs: Stereotypes Undermine Girls' Interest and Sense of Belonging in Computer Science. Journal of Educational Psychology, 108(3), 424. https://doi.org/10.1037/edu0000061

McKinney, V. R., Wilson, D. D., Brooks, N., O'Leary-Kelly, A. and Hardgrave, B. (2008). Women and Men in the IT Profession. Communications of the ACM, 51(2), 81-84. https://doi.org/10.1145/1314215.1314229

Microsoft Corporation. (2017). Why Europe's Girls Aren't Studying STEM. N.P.: Microsoft Philanthropies. Available at: http://hdl.voced.edu.au/10707/427011. (Accessed 21 April 2021).

Minelgaite, I., Sund, B. and Stankeviciene, J. (2020). Understanding the Nordic Gender Diversity Paradox. TalTech Journal of European Studies, 10(1), 40-57. https://doi.org/10.1515/bjes-2020-0003

OECD. (2017). PISA 2015 Assessment and Analytical Framework. Paris: PISA, OECD Publishing. https://doi.org/10.1787/9789264281820-en

Reisel, L. (2014). Kjønnsdeling på tvers, in L. Reisel and M. Teigen (eds), Kjonnsdeling og etniske skiller på arbeidsmarkedet (pp. 30-47). Oslo: Gyldendal Akademisk.

Sagebiel, F. (2016). Gendered Organizational Cultures in German Academic Engineering. Investigaciones Feministas, 7(2), 41-66. https://doi.org/10.5209/INFE.53797

Sammet, K. and Kekelis, L. (2016). Changing the Game for Girls in STEM: Findings on high impact programs and systembuilding strategies. Oakland: Techbridge.

Samordna opptak. (2020). The Norwegian Universities and Colleges Admission Service. Available at: https://www.samordnaopptak.no/info/om/sokertall/. (Accessed 21 April 2021).

Seierstad, C. and Kirton, G. (2015). Having It All? Women in High Commitment Careers and Work-Life Balance in Norway. Gender, Work \& Organization, 22(4), 390-404. https://doi.org/10.1111/gwao.12099 
Simonsen, M. and Corneliussen, H. G. (2020). What Can Statistics Tell About the Gender Divide in ICT? Tracing Men and Women's Participation in the ICT Sector Through Numbers, in D. Kreps, T. Komukai, T. Gopal and K. Ishii (eds), Human-Centric Computing in a Data Driven Society. Cham, Switzerland: Springer. https://doi.org/10.1007/978-3-030-62803-1_30

Statistics Norway. (2018). Women and Men in Norway. Oslo-Kongsvinger: Statistics Norway.

Stoet, G. and Geary, D. C. (2018). The Gender-Equality Paradox in Science, Technology, Engineering, and Mathematics Education. Psychological Science, 29(4), 581-593. https://doi.org/10.1177/0956797617741719

Sund, B. (2015). Just an Illusion of Equality? The Gender Diversity Paradox in Norway. Beta, 29(2), 157-183. https://doi.org/10.18261/ISSN1504-3134-2015-02-04

Teigen, M. (2014). Kjønnsdeling på langs, in L. Reisel and M. Teigen (eds), Kjonnsdeling og etniske skiller på arbeidsmarkedet (pp. 48-64). Oslo: Gyldendal Akademisk.

Teigen, M. and Skjeie, H. (2017). The Nordic Gender Equality Model, in O. Knutsen (ed), The Nordic Models in Political Science. Challenged, but still viable? (pp. 125-148). Bergen: Fagbokforlaget.

Traphagen, K. and Traill, S. (2014). How Cross-Sector Collaborations are Advancing STEM Learning. Los Altos, CA: Noyce Foundation.

Vainionpää, F., Kinnula, M., Iivari, N. and Molin-Juustila, T. (2019). Gendering and Segregation in Girls' Perceptions of IT as a Career Choice - A Nexus Analytic Inquiry, in A. Siarheyeva, C. Barry, M. Lang, H. Linger and C. Schneider (eds), Information Systems Development: Information systems beyond 2020 (ISD 2019 Proceedings). Toulon, France: ISEN Yncréa Méditerranée.

Wemrell, M., Stjernlöf, S., Aenishänslin, J., Lila, M., Gracia, E. and Ivert, A. K. (2019). Towards Understanding the Nordic Paradox: A Review of Qualitative Interview Studies on Intimate Partner Violence Against Women (IPVAW) in Sweden. Sociology Compass, 13(6), e12699. https://doi.org/10.1111/soc4.12699

West, C. and Zimmerman, D. H. (1987). Doing Gender. Gender \& Society, 1(2), 125-151. https:// doi.org/10.1177/0891243287001002002

World Economic Forum. (2020). The Global Gender Gap Report 2020. Switzerland: World Economic Forum.

Citation: Corneliussen, H. G. (2021). Unpacking the Nordic Gender Equality Paradox in ICT Research and Innovation. Feminist Encounters: A Journal of Critical Studies in Culture and Politics, 5(2), 25. https://doi.org/10.20897/femenc/11162

Copyright (C) 2021 by Author/s and Licensed by Lectito BV, Netherlands. This is an open access article distributed under the Creative Commons Attribution License which permits unrestricted use, distribution, and reproduction in any medium, provided the original work is properly cited. 